\title{
„PRIN MEMORIA MEA COMUNIC CU STRĂMOȘII MEI, AI CĂROR SOL ȘI URMAȘ SUNT EU..." (INTERVIU CU VLADIMIR BEȘLEAGĂ)
}

\author{
Nadejda IVANOV \\ Institutul de Filologie Română „Bogdan P.-Hasdeu” \\ ORCID:https://orcid.org/0000-0003-0451-444X
}

\begin{abstract}
Rezumat. În interviul oferit de Vladimir Beșleagă Nadejdei Ivanov, Domnia Sa reflectează despre rolul jurnalului și a memoriilor personale în activitatea sa de scriitor, de istoric, de om de cultură. În cea de-a doua parte a interviului, Maestrul, împreună cu intervievatoarea - o cercetătoare pasionată de proza dlui, discută și analizează valoarea artistică și funcțiile simbolice ale unor imagini recurente din romanele Zbor frânt și Viața și moartea nefericitului Filimon. De asemenea, nonagenarul Vladimir Beșleagă s-a expus despre literatura la zi și rolul scriitorului în societate.
\end{abstract}

Summary. In the interview given by Vladimir Beșleagă to Nadejda Ivanov, the writer reflects on the role of the diary and personal memoirs in his activity as a writer, historian, and man of culture. In the second part of the interview, the Master, together with the interviewer - a researcher passionate about his prose, discusses and analyzes the artistic value and symbolic functions of recurring images from the novels Zbor frânt and Viața și moartea nefericitului Filimon. Also, the ninety-year-old Vladimir Beșleagă spoke about current literature and the role of the writer in society.

Interviu oferit de Vladimir Beșleagă la Institutul de Filologie Română „Bogdan Petriceicu-Hasdeu”, 12 ianuarie 2020.

N.I.: Maestre Vladimir Beșleagă, V-aș ruga să ne vorbiți de la început despre manuscrisul Jurnalul de vise - Vise de noapte și zi care l-ați încredințat doamnei Ana Ghilaș și subsemnatei.

Vladimir Beșleagă: Doamnă Nadejda, dacă e vorba de jurnal, hai s-o luăm de mai departe. Eu am început să țin un jurnal din școală încă. Am aflat de la părintele meu că o cunoștință de-a lui avea jurnal. Știi cine era acea cunoștință? Alexandru Marian, fratele mai mare al lui Boris Marian, scriitor. Fratele lui, fiind elev, a venit la ei, un tânăr jurnalist sau poate scriitor începător care le-a vorbit de jurnal și el s-a prins și a început să scrie jurnal. Am auzit de treaba asta și din clasa a 8-a, iarna, în februarie, am pornit și eu un jurnal. L-am dus până la terminarea școlii - clasa a 10-a. Pe urmă, la facultate, iar am scris un 
jurnal, elementar, că nu mai aveam timp. Am făcut doctorantura și am ținut iar jurnal, din ' 56 până în ' 65 , după care am abandonat și n-am revenit la el decât în ' 86 . Pe parcurs însă aveam câte un carnețel cu mine în care făceam note foarte scurte. S-au adunat 10 - 12 carnete. Abia mai târziu le-am sistematizat. După aceea n-am mai ținut jurnal, abia în '86-'88 am realizat acel jurnal pe care l-am publicat, primul ajuns carte. După aia iar am abandonat. Am revenit la jurnal la începutul noului secol și al noului mileniu, adică în 1 ianuarie 2000, dar după 2-3 luni iar l-am abandonat.

Cu începere din 2003fac consemnări sistematic, zi de zi, până la sfârșitul anului 2019. Din 2003 până în 2019, adică iese vreo 16 ani, zi la zi. S-au adunat mii de pagini!

Acum le revăd. Am sistematizat așa: Un jurnal din 2003, pe urmă 20052007 - alt jurnal. 2005-2007 i-am spus „Jurnal liric”, care a fost publicat în revista "Starea de urgență”, în formă de carte și care se numea „Ochii Stelianei”. Ediția a atras atenția doamnei Nina Corcinschi și dumneaei a scris un eseu entuziasmat, poetic. Din 2008 până în 2010 am procedat la acest jurnal despre care vorbim acum, se numește „Vise de noapte și zi”, care cuprinde aproximativ doi ani și jumătate și conține la mia de pagini sau ceva mai mult. Dar nu se termină povestea aici. În 2010-2012 am scris un jurnal foarte scurt, laconic, căruia i-am spus „Cartea nimicurilor”, pe care sper să-l editez. Acolo surprind viața noastră politică, viața mea spirituală, dar concentrat. Nu mia de pagini! Acela a fost 1000 de pagini, dar ăsta e de 150 - 200, cam aşa. 2010-2012 - atunci când am făcut 80 de ani. După care, în continuare, din 2012 până în 2014 am scris un jurnal vorbit. Am dictat la reportofon timp de doi ani și jumătate tot ce mi se întâmpla, tot ce gândeam, tot ce simțeam, tot ce vedeam, tot ce auzeam, tot, tot, tot! Acest jurnal este grandios, este un mega-jurnal. Dacă ar fi să-l transformăm în pagini, cred că ar fi vreo 3000 de pagini - din 2012 până în 2014.

Or, eu nu făceam doar notații politice sau despre evenimente. Jurnalele mele în fond sunt ceea ce mi se întâmplă momentan, ceea ce-mi atrage atenția. Ideile, gândurile care îmi vin în minte, dar în special retrospectiva, adică amintiri. Componenta prezentului este completată sau alimentată de memorie. Le spuneam așa, când făceam o notație/o consemnare: „Din memoria spontană”. $\mathrm{Nu}$-mi propuneam anume să-mi aduc aminte, dar prin analogie, prin asociație apărea un fenomen. Adică ceea ce mi se întâmpla în realitate, la moment, în actualitate avea rezonanță sau ecou în fapte din memorie prin asociații și prin analogie. Deci, ele pot fi considerate și jurnal, și memorii. Ori, dacă luăm și a 
treia componentă, acestea ar fi visele. Altă componentă ar fi realitățile politice.

Domnul Nicolae Popa a activat o vreme la revista „Moldova” și mi-a solicitat impresii despre evenimentele din 7 aprilie 2009. Rebeliunea tinerilor, eveniment grandios! Ceea ce țineam minte era una, dar am mers la jurnal și am găsit consemnări la zi. Cum s-a întâmplat, cum am venit în piață, când am venit. Manifestările au început pe 7 aprilie pe la 12 sau 13, eu am sosit la ora 17. Eram ocupat cu probleme de mașină, pe la meșteri și m-am reținut. Când am ajuns în piață, piața clocotea! Deci, am consemnat tot ce am văzut. I-am oferit lui textul și aceste note/consemnări pentru revista „Moldova” şi ele s-au publicat. Deci, în afară de ceea ce mi se întâmplă mie, ceea ce se produce în ideile mele, în gândirile mele, visele, memoriile, asociațiile, în jurnale surprindeam și evenimentele politice, la zi.

Am încheiat jurnalul vorbit la un reportofon tradițional (nu din ăsta digital, dar tradițional cu panglică magnetică). Asta, din 2012 până în 2014. După aceea, din 2015 până în 2019 iar am urmat un jurnal, dar mai compact, mai econom. Or, acele două, „Visele” și vorbit (fono-jurnal) unul -1 000 de pagini, altul e vreo 2000 -3 000, iar celelalte trei sunt compacte - câte 100-120 de pagini. Între ele am un „Jurnal liric”, cu consemnări în versuri, versuri libere.

N.I.: Care este totuși importanța acestor jurnale în viața Dvoastră? Retrospectiva are un rost anume în procesul de înțelegere de sine?

Vladimir Beșleagă: Există o lege. De la Goethe citire: „Dacă ai de gând să-ți scrii memoriile trebuie să începi de la 50 de ani. După 50 de ani memoria omului slăbește”. Eu am început în adolescență. Am lăsat. Când am ajuns la 60, cu întârziere de 10 ani, mi-am amintit de adevărul emis de Goethe și am pornit să lucrez la reportofon. Am dictat 18 casete, pe care le-am descifrat și ele au format jurnalul din '86-'88, plus, notele în '89. De ce este important să-mi aduc aminte? Pentru că viața omului este foarte grăbită, lucrurile se șterg, se uită, iar prin rememorare, ca și cum ai trăi a doua oară și ca și cum ai valorifica propria existență. Am avut o viață zbuciumată, am avut momente foarte grele, începând din adolescență, ba chiar din fragedă copilărie. Relația dintre părinții mei a fost tensionată, pentru că a lor căsnicie s-a făcut într-o perioadă de mari răsturnări sociale. Bunelul meu de pe mamă a fost deportat, mama rămasă singură, tânără, s-a măritat repede. De nevoie, pentru că altfel era să fie deportată și ea. S-au adunat, am apărut eu și la 4 ani au divorțat. Dar au continuat să conviețuiască, numai de dragul meu, dar n-a fost înțelegere între ei. Or, când am crescut, am devenit adolescent, și am pornit să analizez viața mea proprie, a familiei mele, a neamului meu, mi-am dat seama că eu sunt un produs al unei nenorociri, a unei 
tragedii. Bunelul meu de pe mamă a avut un fiu, care se numea Alexandru (12 ani). Când a fost deportat s-a dus și fiul cu tata și n-au trăit nici doi ani, un an de zile și au murit amândoi. Bunelul - de boală, de dezinterie, iar fiul sfâșiat de lupi în pădurile Rusiei. Atunci mi-am zis: „Eu am venit pe lume cu prețul vieții lor și nu am dreptul să trăiesc pe lumea asta”. A fost prima mea criză la 17 ani, când am vrut să-mi iau zilele. A fost un șoc puternic, după care au urmat alte şocuri: pierderea mamei, pierderea fiului. De la 2000 încoace, țin jurnale, care sunt și memorii. Pe parcurs am avut pauze. Ai să ajungi dumneata și ai să începi să-ți cerni și să-ți decantezi viața și să vezi, pentru că una este să trăiești viața, dar pe urmă trebuie să pleci, iar înainte de a pleca trebuie să-ți dai seama ce-a fost viața asta, cum a fost, dar de ce a fost așa și nu altfel, pentru că e greu să trăiești, ai probleme, dar să mori e și mai greu. Cum a zis poetul? „Nu credeam să învăț a muri vreodată." Omului i se dă viața nu ca să o trăiască în plăceri, ci ca să învețe a muri.

Ca să nu uit. Deci, lucram în spatele casei mele - construiam eu un loc, un teren, o bază pentru un garaj. Pe acel loc fuseseră, pe timpul bunelului, grajdurile lui. Sigur că nu mai rămăsese nimic, se dărâmaseră. Săpând eu așa, am descoperit un fel de, nu cataramă, ci de floare, cum i s-ar zice în termeni elementari bleahă. Un fel de element de pe harnașament, de pe hamuri, pe care-l purtau caii, erau niște piese, lucruri decorative. A zăcut acolo, în pământ, și când am dat cu hârlețul, a scrâşnit. L-am luat, l-am ridicat. Dar era de bronz, cu rugină. L-am curățat de pământ. Am avut un șoc! Atâta a rămas de la bunelul! Pentru că de la el n-a rămas nicio fotografie, nimic! nimic nu a rămas. Numai amintirile câte le-am auzit. Zic: „Uite cum s-a întâmplat că imediat s-a declanșat toată povestea, toată tragedia vieții lui." Pentru că el ce-a fost? Când s-au început colectivizările, dar prin părțile noastre, pe la început, se înjghebau așa-zisele SOZ, un fel de asociație de muncă în comun a pământul - SOZ Sovmestnaia Obrabotka Zemli, pe urmă la trecut la colhozuri. Bunelul a intrat în acea asociație și când a văzut că acolo s-au adunat toți trântorii și bețivii, dar ei, gospodarii, lucrează, muncesc, așa cum munceau și la dânșii acasă, dar aceia cu fumatul și cu băutul și a ieșit! Pentru asta a fost judecat pe un an de zile și a fãcut muncă silnică. După un an de zile ce-a făcut? S-a întors acasă, avea ascunsă pâine în gunoi, a vândut pâine, și-a cumpărați alți cai, căruță, că ai lui erau dați în societatea ceea. Și-a cumpărat căruță, boronă, plug și a început iar să lucreze. În '33, iarna, arestat, deportat și la anul - mort. Când am dat eu peste bucata ceea de metal m-a izbit toată durerea asta și mi-am zis așa: „Iată eu trăiesc, iată eu sunt pe lume, iată eu am viață, dar el de ce nu 
este?” Eu am vrut să-l cunosc, să-l știu și n-a rămas nimic de la dânsul. Când am ajuns să-l citesc pe Jung și să mă familiarizez cu teoria lui, am văzut că bunelul trăiește în mine. Fie că știu eu ori nu știu eu! Vreau eu ori nu vreau! Dar el este în mine! Asta e teoria și asta e descoperirea cea mare a lui Jung, care s-a distanțat de Freud și a fondat școala lui.

N.I.: Știm cu toții că amintirile au un rol special și în opera Dvoastră. Care a fost destinul romanelor Dvoastră?

Romanele mele au avut destinul lor aparte, în sensul că am început să scriu, să mă produc ca autor cu nuvele mici, pentru că ăsta era ritmul meu și asta era modalitatea mea de a mă exprima. Dar, în același timp, visam la o carte mare, simțeam că aș fi în stare s-o realizez. Perioada de gestație, de acumulare a durat mult. Am început cu poezii și proze scurte din școală încă, din clasele a șaptea, a opta, iar romanul l-am abordat abia în '65. Câți ani au trecut din '47? 12, 15? Mai mult - 18 ani! Deci, asta a fost perioada de pregătire, de gestație, de acumulare... Și cum s-a întâmplat? Romanul „Zbor frânt” a apărut imediat după ce am pierdut-o pe mama. Am trăit atât de profund pierderea ei! A fost o catastrofă, era să mă desființez. Pentru că am ținut foarte mult la mama și am găsit o modalitate - am revenit la un subiect mai vechi și am scris cartea în trei luni de zile. A fost ca o revărsare, ca o revelație, ca un miracol! Dar să nu uităm că la baza acestui roman nu e pur și simplu intuiție, eu am făcut doctorantură. Am studiat Rebreanu, am studiat serios genul romanului, am studiat, eu am studiat istoria romanului. Deci, nu veneam ca un naiv sau ca un neofit sau ca un amator. În afară de asta, în perioada aceea s-a produs fenomenul noul roman francez - Natalie Sarrot, Alain Robbe - Grillet.

Romanele mele au fost concepute dintr-un impuls foarte puternic, din șocuri existențiale, din dureri, din mari pierderi. Vedeam cum făceau colegii mei. Îmi ziceam: „Dacă aș proceda ca ei, în fiecare an aș scrie câte patru-cinci romane." Eu am scris doar atunci când nu puteam să nu scriu! Și iată așa s-a întâmplat că am pierdut-o pe maică-mea și s-a născut această carte de mare durere și i-am închinat-o memoriei mamei mele.

Ulterior am conceput alte două romane după ‘65 - '66. Unul se numea „Moartea Albinei”, din cinci nuvele, pe care l-am pornit și nu s-a realizat, pentru că m-am îmbolnăvit. Am avut iar necazuri mari. A rămas din el o singură nuvelă - „Pădurea albastră”. Apoi am început un alt roman, care se numea „Femeia cu buzele albe” și iar a eșuat, n-am putut să-l duc până la capăt. A rămas iar o nuvelă - „Cel de-al treilea dacă ar fi fost acolo”. Pe urmă, bolnav cum eram, mi-am spus așa: „Dacă am început să lucrez la un text, la 
o carte, la un subiect, mort-copt trebuie să-l duc la sfârșit! Or, după ce-am ratat două cărți, am conceput „Noaptea a treia”. „Noaptea a treia” s-a produs într-o epocă a crepusculului, a căderii satârului cenzurii, când intra în perioada marelui întuneric. Or, perioada de liberalizare de după moartea lui Stalin,s-a încheiat prin anul '68. Anul '68 a fost un an de hotar. Atunci a apărut cartea lui Grigore Vieru „Numele tău”. În 1968, în revista „Nistru”, a apărut nuvela de mare protest și răsunet a Lidiei Istrati „Îngăduie omule”, unde se făcea un protest sistemului fals și vândut, și corupt al colhozurilor. Era o tânără agronomă, care a fost blamată și timp de 12 ani n-a mai publicat nimic.

De la acest an a început perioada marasmului, care a durat până în anii ' 80 , când autorii noștri au scris lucrări conformiste, laudative la adresa lui Bodiu cu complexele lui de porci și bovine, cu bălegarul lui. Această carte a mea „Noaptea a treia” s-a scris iarăși din durere. Atunci am simțit că gata, s-a terminat cu libertatea noastră de creație. Este o carte întunecată, o carte tragică și a avut un destin tragic. Când am pornit să lucrez la ea, pe la jumătate, iarăşi m-am îmbolnăvit. Fiind în spital, mă sculam noaptea, ieșeam din salon, mergeam la bucătărie unde era lumină și lucram. Știam că dacă las iar, nu o mai duc la capăt, ca celelalte două subiecte, eșuează și asta. Am terminat-o, dar știam dinainte că n-o să se publice. După ce am dactilografiat-o, am dat-o la câțiva colegi, au citit, vreo zece colegi au citit-o și au fost foarte impresionați. Când a ajuns la publicare, a fost distrusă! Lucram secretar literar la revista „Nistru” și am propus-o pentru publicare. Redactor-șef era Bucov. La discuție s-a adunat colegul de redacție, eu - secretar, îți închipui? La revista la care lucrez, eu am fost distrus. Bucov a declarat așa: „Am citit, nu-i așa? (avea el o vorbă), până la pagina 13 și mai mult n-am putut să citesc, că e o carte întunecată, e o carte așa, e o carte aşa.”

Cel care s-a produs magistral știi cine a fost? Alexandru Cosmescu! Era un om cult, era versat, nu era ca Bucov un dogmatic. Dânsul a izbit în manuscris și în mine. Care a fost capătul de acuzare? Argumentul de bază? Aveam acolo un personaj cu numele de Moja. Era un fel de umbră a lui Nichifor Fătu. Cosmescu îmi spune: „Dar dumneata știi ce înseamnă Moja?” Zic: „Nu știu.” "Ăsta e diminutivul de la Moișile.” Dar Moișile se știe cine e. Zic: „N-am știut.” Pe urmă, când am editat cartea, l-am schimbat în Guja. Deci, el m-a acuzat de antisemitism. Dar eu de unde am luat numele acela? Aveam un coleg la facultate care se numea Ivan S,pac, care a lucrat aici bibliotecar.

N.I.: Am auzit de dumnealui, dar sigur că nu l-am apucat.

Vladimir Beșleagă: El venea de la Camenca sau de la Râbnița, dintr-o 
localitate, oraș unde erau mulți evrei. Îmi povestea pătărănii de-a lui, din copilărie, și îmi oferea nume. Am avut o nuvelă pentru copii și la un câine i-am dat numele Șulem, nume de la dânsul luat. Șulem înseamnă Șolom, tot evreiește. Și Moja tot de la dânsul auzit... Acuma ce se întâmplă cu acest manuscris, cu această carte? Propun niște fragmente. S-a publicat un fragment la revista „Moldova” sau la „Femeia Moldovei”, pe urmă, l-am prezentat la editură. Așa era regula, Nadejda: orice carte, orice manuscris, înainte de a merge la editură trebuia să fie publicat în presă, discutat în secția respectivă de la Uniunea Scriitorilor, pe urmă discutat la editură, abia apoi publicat! Odată ce manuscrisul a fost rebutat la revistă, nu mai avea șansă să fie editat, gata, s-a terminat! Dar la editură totuși a fost recenzat. Cine era acolo? Sergiu Nucă, dacă ai auzit. Editura așa proceda: dădea la recenzie, la 2-3 inși, asta se numea recenzie internă. Printre recenzenții interni, care s-au pronunțat asupra acestui manuscris „Noaptea a treia” a fost Haralambie Corbu. Haralambie Corbu a scris o recenzie închisă, foarte pătrunzătoare. A simțit, avea cultură, avea tot, dar era și un mare cenzor! A îngropat multe cărți, nu numai a mea. A acuzat cartea că e închisă „sub șapte lăcăți”, cum scria el, șapte lacăte. Într-adevăr nu este o carte deschisă, pentru distracție, pentru amuzament. Este o carte îndurerată, în care m-am exprimat. Când sunt întrebat: „Care dintre cele două sau trei cărți vă reprezintă?”, răspund: „Asta mă reprezintă - Noaptea a treia. Acolo eu sunt cu toată firea, ființa, tragismul și durerile.”

N.I.: Vă mulțumesc foarte mult, Maestre, pentru aceste mărturisiri cutremurătoare!

Interviu oferit de Vladimir Beșleagă la Institutul de Filologie Română „Bogdan Petriceicu-Hasdeu”, 16.02.2021

N.I.: Domnule Vladimir Beșleagă, mă bucur că avem posibilitatea să continuăm discuția noastră cu privire la operă și aș vrea să știu dacă ați meditat vreodată la funcția simbolică a copilăriei din romanele Dvoastră? De ce ați optat ca personajele Dvoastră să graviteze în jurul imaginilor-arhetipale casa, mama, tata, satul? Cât de importante vi se par acum în reconstituirea traseului către sine?

Vladimir Beșleagă: Să fi meditat vreodată? Poate, dar asta mai târziu, nu în perioada redactării romanelor, la care vă referiți. Or, forțelor arhetipale se manifestă/lucrează în sufletele și existența noastră în afara conștientului. Atunci când mă refer la arhetipuri, am în vedere, mai întâi, predecesorii mei, buneii, străbuneii, imbold pe care l-am resimțit de timpuriu, pentru că au avut 
o soartă tristă, chiar tragică: au fost deportați, au murit departe de casă... Zicea maică-mea despre părintele și fratele mort în război, pe alte meleaguri: „Eu, dacă oi muri, mă-ți îngropa, măcăr veți ști unde mi-i mormântul, dar oasele tatei și a lui badea cine știe pe unde putrezesc!”

Iar satul? Este o lume cât lumea de mare: în el m-am născut, în el am crescut... Un detaliu semnificativ și caracteristic: ori de câte ori mergeam la oraș cu tata și vedeam acolo copii, ca mine, mi se arătau palizi, slăbănogi, ca niște arătări! Eu eram ars de soare, vânjos - ei artificiali! Faptul că am ajuns la astă vârstă înaintată o datorez anume satului meu...

În concluzie: omul nu este decât o verigă în lanțul generațiilor premergătoare, de unde și marea forță a strămoșilor în destinul lui...

N.I.: Mărturisiți în mai multe interviuri și jurnale că mama este cea mai aproapiată ființei dvoastră. În imaginarul creaţiei dumneavoastră Mama este personajul simbolic ce sondează ființa protagoniștilor și ocrotește cu natura ei casa și identitatea personală. De ce însă prezența ei în textele literare este asociată cu o mare tragedie a omului și a neamului basarabean? Cauza ar fi că astfel vi s-a imprimat chipul ei în sufletul dumneavostră de copil - mereu îngrijorată - în contextul presiunilor socio-politice de atunci?

Vladimir Beșleagă: Adevărat, mama a fost pentru mine cea mai apropiată și scumpă ființă din lume - eu fiind singurul ei copil. M-a adus pe lume fiind și ea aproape un copil - la 17 ani, dat fiind că s-a căsătorit în timpuri grele, ca să scape de urgiile sistemului totalitar... Mi-a fost mamă, dar și prima învăţătoare - ea m-a deprins cititul. Mi-a cultivat simţul cuvântului frumos. Mi-a sădit în suflet aplecarea spre umor, spre poezie.

Apropo, am avut în sat un poet popular, Iftode Chiorul, care vorbea în versuri: Prin mama am cunoscut un catren de-al lui despre viaţa omului. Zicea așa: „Se scurtează pasul./Slăbește glasul./Se subție nasul./Se apropie ceasul.”

A avut mamă-mea o viață grea cu soțul ei, tatăl-meu - mereu conflicte, amenințări că o omoară. Eu totdeauna îi luam apărarea strigând: „Nu împușca pe mamaia!" Am avut o cumpănă mare: de spaimă era să mă prăpădesc, dar m-a salvat bunica Natalia, care m-a dus la o vrăjitoare, ce m-a descântat...

Când aveam vreo 4 anișori, părinții au divorțat, dar au continuat să conviețuiască. S-a stins maică-mea devreme, de o boală incurabilă...

N.I.: Imaginea Tatălui pe de altă parte este total opusă Mamei. Nu este una complementară ei. Tata este cel care scindează ființa protagonistului din "Zbor frânt” prin absența lui și „Viața și moartea nefericitului Filimon”, prin afectarea directă a integrității copilului. Spuneți-ne, vă rog, aceste valențe 
negative de înstrăinare a protagoniștilor de sine însuși sub influența Tatălui (Nechifor Fătu) este o experiență afectivă ce ilustrează și soarta/ condiția existențială într-o societate totalitară?

Vladimir Beșleagă:E o întrebare!

Bărbatul și Femeia sunt ca doi poli ai existenței umane - unul fără altul nu pot să existe. Se zice că bărbatul este întruchiparea forței, femeia - a slăbiciunii. Asta la modul abstract, ideal. De fapt, în fiecare om, fie el bărbat sau femeie, sălășluiesc ambele principii - și cel masculin, și cel feminin, depinde care din ele prevalează, acela o definește...

La concret. La întrebare. Tatăl meu a fost un om foarte binevoitor, bun la suflet, săritor la nevoie. Avea metehnele lui, printre care - paharul. Sfădăliile lui se iscau când era băut - încolo bun de pus la rană. În ceea ce privește personajul din romanul „Viața și moartea...”, țin să specific că e unul din domeniul ficțiunii, care nu are nimic în comun cu părintele meu - ba chiar un antipod. Așa mi-a cerut structura narațiunii! Să ne amintim că tatăl lui Isai a fost victima sistemului totalitar... Pe când Nichifor Fătu anume reprezintă esența acelui sistem!

Da, doamnă Nadejda - în subtextul acestei cărți se mai află incifrate și alte semnificații, mult mai profunde decât cele observate de critica literară la care analiștii noștri încă nu au ajuns.

E bine așa...

N.I.: Ce loc ocupă literatura în sufletul Dvoastră?

Vladimir Beșleagă: Literatura?

Sunt de la 5-6 ani un cititor pasionat.

Toată viața am citit - lectura a fost ca și cum aerul meu. Erau perioade când citeam câte trei cărți pe zi - ba chiar și la lumina Lunii!

De la lecturi mi-a venit și patima scrisului - cum altfel? Am scris totdeauna când m-a durut, m-a fript la inimă. „Zbor frânt” a fost redactat în câteva luni din suferința pierderii mamei mele. „Filimon” a apărut în condițiile impunerii drastice a cenzurii comuniste, astfel că nu a putut să fie publicată abia târziu „Cumplite vremi” a fost conceput și realizat tot din durerea arestării cărții despre destinul lui Filimon...

Scriu din durere, numai atunci când mă arde la inimă...

N.I.: V-aţi întrebat vreodată, cum și cât de mult a influențat fenomenul pierderii/ mutilării identităţii culturale (anexarea Basarabiei la URSS) asupra devenirii personale și creatoare? Tot ce ați gândit și ați scris reprezintă chintesența vieții Dvoastră? 
Vladimir Beșleagă: „Chintesența vieții mele..”

Sunt tocmai la vârsta, la care mereu îmi recapitulez/rememorez ceea ce am trăit și am fost în viața aceasta, decantez evenimentele, situațiile, peripețiile vieții mele, pornind de la copilărie până încoace...

A fost o viață plină de zbucium și trăiri, și cumpene, dar și de realizări... Dacă e să mă refer doar la activitatea mea de autor, voi spune că am avut marele noroc să mă formez ca om de cultură, dar și ca literat într-o epocă de un relativ regim de liberalizare de după moartea tiranului Stalin...

Și eu și generația din care am fãcut parte... Asta pentru că s-a deschis poarta, prin care peste un deceniu am comunicat cu marea literatură și cultură română, pe lângă faptul că eu făcusem în timpul războiului o clasă primară și un an și jumătate de liceu românesc. Fără a te alimenta cu minunata carte românească nu aș fi ajuns niciodată scriitorul care, sper, sunt...

N.I.: Romanele Dvtră reprezentative au fost scrise sub influența experiențelor lăuntrice. Putem considera că opera literară trebuie totuși să izvorască dintr-o profunzime a sufletului artistului, să se ridice la înălțimea trăirii sale și să o plăsmuiască în imagini?

Vladimir Beșleagă: Aici voi fi succint, aproape telegrafic.

Există cărți scrise... din cărți...

Există cărți rupte din ființa ta!

Primele sunt așa-zisele „opere” combinatorii. Eu, precum am mărturisit anterior, am scris doar atunci când m-a durut, dar rău de tot! (Am în vedere beletristica, nu jurnalele sau publicistica, deși și... aici... e mult din inima mea!)

Ca să fiu mai explicit! A scrie ceva nu e mare lucru. Ce pui tu din tine însuți - asta contează!

N.I.: Care este rolul literaturii în zilele noastre? Care ar fi sfatul prețios pentru tinerii creatori de literatură?

Vladimir Beșleagă: E trist să consemnez, dar e o realitate - trăim perioada Amurgului Epocii Gutenberg.

Cartea, odinioară odor de căpătâi, a ajuns să fie împinsă la marginea interesului public... Dar ea, Cartea Mare, există!

Își modifică aspectul, forma, dar ca esență rămâne o forță, una importantă... Școala oficializată nu cultivă dragostea pentru carte, din contra - indiferența! Un cititor, ca și un autor, e unul de vocație. Un cititor se cultivă/se formează de acasă, din familie, de la mama... Or, mama e cea care sădește în sufletul copilului ei pasiunea pentru lectură - mai târziu e foarte târziu! Iar pentru tinerii creatori am o singură îndru- 
mare: „Înainte de a încerca să creezi o operă, creează-te pe tine însuți!” Ceea ce înseamnă: ca să vii la cititor cu o carte, citește mai întâi tu un Everest de cărți, suferă tu și gustă viața din plin, ca să ai din ce te alimenta și ce oferi cititorului tău...

N.I.: La cartea „Mama Casa Pământul” mi-aţi oferit un autograf „Pentru Nadejda Ivanov, cea care a coborât în infernul lui Filimon”. Să știți că țin foarte mult la el...

Vladimir Beșleagă: „În Infern?”

Am o notație lirică, din care reproduc aici primul catren: „Copil, mi se păru că Viața-i Paradis./Bătrân, am înțeles, că nu-i decât Infern! Efemeridă/ - Eu, Tu, Timpule Etern,/De astăzi mă retrag/Să locuiesc în vis!...”

Așa cum v-am mărturisit în dialogul nostru ce-a avut loc la Academie, de la o vreme țin Jurnal. Prin Jurnal comunic cu Trecutul. Trecutul este Memoria Mea... Prin Memoria mea comunic cu strămoșii mei, ai căror sol și urmaș sunt Eu... Studiile Dumneavoastră, dna Nadejda, vin să mă susțină în această comunicare sacră cu înaintașii mei...

Țin să amintesc și să mulțumesc pe această cale doamnei profesor Ana Ghilaș, a cărei discipolă sunteți și să vă urez noi succese în munca nobilă pe care o practicați cu multă inspirație.

N.I.: Vă mulțumesc din suflet, Maestre! Sunt fericită de fiece dată să recitesc romanele Dvoastră și onorată pentru interviul oferit!

Notă: Articolul a fost realizat în cadrul proiectului de cercetare 20.80009.1606.03 Contexte socio-culturale autohtone și interconexiuni europene în creația populară și literatura cultă din Basarabia (sec. XIX până în prezent), Institutul de Filologie Română „Bogdan Petriceicu-Hasdeu” al MECC. 